\title{
Predicting grazing mortality of an estuarine dinoflagellate, Pfiesteria piscicida
}

\author{
Diane K. Stoecker ${ }^{1, *}$, Daniel E. Gustafson \\ University of Maryland Center for Environmental Science, Horn Point Laboratory, PO Box 775, Cambridge, Maryland 21613, USA
}

\begin{abstract}
Grazing can prevent or substantially decrease net growth of phytoplankton populations if grazing coefficients are similar to or greater than growth coefficients of the phytoplankter. Potential grazing by microzooplankton on small dinoflagellates $(<20 \mu \mathrm{m})$, such as Pfiesteria piscicida, can be high, but extremely variable in estuaries. Blooms should only be possible during 'windows of low grazing pressure'. To better understand this variability, microzooplankton assemblages were collected at stations with low ( 5 psu), medium ( 10 psu) and high ( 15 psu) salinity on the Pocomoke River, MD, and their grazing on cultured, stained non-toxic P. piscicida zoospores was measured. Grazing coefficients varied from 0 to $7.6 \mathrm{~d}^{-1}$. On most dates average grazing coefficients were $>2 \mathrm{~d}^{-1}$, indicating that microzooplankton grazing had the potential to regulate densities of non-toxic zoospores. Potential grazing was positively correlated with salinity, abundance of photosynthetic and heterotrophic dinoflagellates and with abundance of $<20 \mu \mathrm{m}$ planktonic ciliates. Grazing on zoospores was negatively associated with abundance of cryptophytes. Approximately $26 \%$ of the variation in grazing coefficient could be predicted from salinity, whereas $67 \%$ of the variation could be predicted from abundance of cryptophytes, dinoflagellates and small ciliates. Net growth of nontoxic zoospore populations is most likely in low-salinity waters with abundant cryptophytes but with low concentrations of microzooplankton.
\end{abstract}

KEY WORDS: Harmful algal blooms · Biological control · Dinoflagellates · Microzooplankton grazing • Pfiesteria piscicida $\cdot$ CMFDA $\cdot$ Chesapeake Bay $\cdot$ Pocomoke River

Resale or republication not permitted without written consent of the publisher

\section{INTRODUCTION}

Pfiesteria piscicida (Dinamoebiales: Pyrrhophyta) has been linked to toxic events and fish kills along the Atlantic coast of the USA (Burkholder et al. 1992, 1995, 2001, Steidinger et al. 1996). In the Chesapeake Bay region, Pfiesteria-like dinoflagellates were linked to fish kills or fish lesions in 1997 in the lower Pocomoke River, the Manokin River, and Chicamacomico River, all subestuaries on the Eastern Shore of Maryland, USA (Maryland Department of Natural Resources 1998, Burkholder et al. 2001).

Pfiesteria piscicida zoospores vary in their toxicity to fishes and palatability to grazers (Burkholder et al. 1992,

${ }^{*}$ E-mail: stoecker@hpl.umces.edu
2001, Marshall et al. 2000, Stoecker et al. 2001). Zoospores are classified as TOX-A (actively toxic), TOX$\mathrm{B}$ (temporarily non-toxic in the absence of live fishes, but capable of toxicity) and NON-IND (undetectable toxicity in the presence or absence of fishes) (Burkholder et al. 2001). The distribution and abundance of TOX-A, TOX$\mathrm{B}$ and NON-IND zoospores in nature is not known. It is usually assumed that populations of TOX-B zoospores grow in the plankton as mixotrophs eating small algae and that toxicity is induced (e.g. TOX-B transformed to TOX-A) in the presence of dense schools of fishes (Burkholder \& Glasgow 1997a,b). Toxic zoospores may also be recruited from amoebae and resting cysts in the presence of dense schools of fish (Burkholder et al. 1992, Burkholder \& Glasgow 1997b).

For a net increase in a population, the growth rate has to be higher than the mortality rate, unless recruitment 
is supplying new individuals. In culture, the maximum growth rates for Pfiesteria piscicida non-toxic zoospores are between 1 and $2 \mathrm{~d}^{-1}$, with most reported rates closer to 1 (Glasgow et al. 1998, Stoecker et al. 2000, Burkholder et al. 2001). Both protistan and metazoan grazers have been observed to consume zoospores (Burkholder \& Glasgow 1995, Mallin et al. 1995, Stoecker et al. 2000). In an investigation conducted in the summer of 1999, we found that potential grazing coefficients on NON-IND zoospores in the Chicamacomico River were usually $>2 \mathrm{~d}^{-1}$ (Stoecker et al. 2000). These data indicate that microzooplankton grazing may be important in preventing net growth of non-toxic (i.e. TOX-B and NON-IND) populations of zoospores in situ.

Although Pfiesteria piscicida can grow over a wide salinity range, the optimum for growth in culture is 15 psu (Burkholder \& Glasgow 1997a). It is interesting that toxic outbreaks have often occurred at a salinity lower than optimum for growth of $P$. piscicida. For example, in 1997, the toxic area on the Pocomoke River was between 7 and 11 psu, on the Manokin (Kings Creek branch) between 0.5 and $10 \mathrm{psu}$, and in the Chicamacomico River $<10$ psu (Maryland Department of Natural Resources 1998). It is possible that net growth of P. piscicida zoospores was higher at low salinity because mortality due to grazing was lower, algal prey was more abundant, fish populations that induced toxicity were more abundant, or a combination of these factors.

Our objectives were to (1) determine if microzooplankton grazing has the potential to regulate net growth of Pfiesteria piscicida non-toxic zoospores in the Pocomoke River; (2) compare potential grazing at high-, medium- and low-salinity stations; and (3) determine if potential microzooplankton grazing on zoospores was correlated with abundance of potential grazers and prey of $P$. piscicida.

Information on grazing pressure on Pfiesteria piscicida and the factors that regulate it may be useful in predicting the antecedent conditions necessary for toxic outbreaks in the presence of fishes because blooms of TOX-B (not actively toxic) zoospores probably precede toxic events. Several other species of small algae have been implicated in harmful algal blooms (Hallegraeff 1993, Glibert et al. 2001), and it is possible that their populations are regulated by microzooplankton grazing as well (Kamiyama 2000). Understanding the factors associated with high or low grazing is important in predicting blooms of harmful algae.

\section{MATERIALS AND METHODS}

Culture and staining of Pfiesteria piscicida. Cultures of $P$. piscicida (Strain MDFDEPMR23) had been isolated from a stored sample from the Chicamacomico
River, MD, grown on an algal enrichment, and was provided to us by Dr. K. A. Steidinger on 10 December 1998. It's identification as P. piscicida had been confirmed using scanning electron miscrocopy (SEM) (Steidinger pers. comm.). Strain MDFDEPMR23 has not been shown to be toxic in bioassays with fish and is thus considered 'non-inducible' with regard to toxicity (J. M. Burkholder pers. comm.).

Cultures were maintained in seawater media at $20^{\circ} \mathrm{C}$ with added cryptophyte (Storeatula major) prey as described in Stoecker et al. (2000), except that cultures were grown at 5, 10 and $15 \mathrm{psu}$. Dense cultures $\left(10^{3}\right.$ to $10^{4}$ cells ml $^{-1}$ ) of Pfiesteria piscicida with low concentrations of algal prey $\left(<50\right.$ cells ml$\left.^{-1}\right)$ were stained for $1 \mathrm{~h}$ with $1 \mu \mathrm{M}$ CMFDA (5-chloromethyfluorescein diacetate, Molecular Probes). Stained cells have green fluorescence but remain motile and capable of division ( $\mathrm{Li}$ et al. 1996, Stoecker et al. 2000).

Enumeration of Pfiesteria piscicida stained with CMFDA. To enumerate cells in stained cultures, 3 to $5 \mathrm{ml}$ fixed with glutaraldehyde $(1 \%$, final concentration) samples were gently filtered $(<15 \mathrm{~mm} \mathrm{Hg}$ pressure) onto $2 \mu \mathrm{m}$ pore-size black-membrane filters and then mounted on glass slides with immersion oil (Resolve) under a cover slip. Slides were enumerated with epifluorescence microscopy at 200× with a Nikon Eclipse standard microscope (Nikon filter set EF-4 B$2 \mathrm{~A}_{\text {; }}$ exciter filter 450 to $490 \mathrm{~nm}$, dichromatic beam splitter $500 \mathrm{~nm}$, barrier filter $515 \mathrm{~nm}$ ). The procedure for enumerating stained $P$. piscicida in samples from the grazing experiments was similar, except that $3 \mathrm{ml}$ samples were filtered and slides were stored frozen at $-20^{\circ} \mathrm{C}$ until counted.

Enumeration of phytoplankton and microzooplankton in water samples. Samples were fixed with cold glutaraldehyde ( $1 \%$ final conc.) and stored at $4{ }^{\circ} \mathrm{C}$ in the dark for enumeration of phytoplankton and heterotrophic dinoflagellates. Aliquots ( 3 to $5 \mathrm{ml}$ ) of the glutaraldehyde-fixed samples were stained with proflavin (final concentration $5 \mathrm{\mu g} \mathrm{ml}^{-1}$ ), gently filtered $(<15 \mathrm{~mm}$ Hg pressure) onto $2 \mu \mathrm{m}$ pore-size black-membrane filters, and then mounted on glass slides with immersion oil (Resolve) under a cover slip (Sieracki et al. 1993). The dominant micro- and nanophytoplankton (photosynthetic dinoflagellates, cryptophytes and centric diatoms) and $<20 \mu \mathrm{m}$ heterotrophic dinoflagellates were enumerated using epifluorescence microscopy (Nikon filter set EF-4 B-2A; exciter filter 450 to $490 \mathrm{~nm}$, dichromatic beam splitter $500 \mathrm{~nm}$, barrier filter $515 \mathrm{~nm}$ ) at 200x. In addition, Pfiesteria-like dinoflagellates (defined here as $\sim 10$ to $15 \mu \mathrm{m}$ gymnodinioid dinoflagellates without their own plastids) were also enumerated separately.

Samples from the water used in the experimental incubations were also fixed with acid Lugol's solution 
(5\% final conc.) for enumeration of planktonic ciliates, $>20 \mu \mathrm{m}$ heterotrophic dinoflagellates and metazoan microzooplankton. $25 \mathrm{ml}$ aliquots were concentrated by sedimentation in Utermöhl chambers and examined on a Nikon Eclipse inverted microscope.

Determination of potential grazing on Pfiesteria piscicida. Surface water samples were collected from a small boat at 3 stations in the Pocomoke River and nearby Sound on 2 occasions in May, 3 in August, 1 in September and 1 in October 2000 (Fig. 1). Stations were chosen on each date so that water of high $(\sim$ $15 \mathrm{psu})$, medium ( 10 psu) and low ( 5 psu) salinity could be obtained. Thus, the position of the stations depended on freshwater flow and tides and varied from date to date (Fig. 1). Samples were passed through a $200 \mu \mathrm{m}$ mesh size to remove larger zooplankton as the water was gently poured into a 11 capacity wide-mouth polycarbonate bottle. At the time of sample collection, water temperature and salinity were measured using a YSI 30 salinity-conductivitytemperature meter.

The water samples were transported in a cooler to Horn Point Laboratory and the grazing experiments initiated within $4 \mathrm{~h}$ of sample collection. All incubation bottles were made of polycarbonate and had been acid-washed, rinsed with distilled water, and sterilized before use. For each water sample there were 2 treatments, with duplicate incubation bottles for each treatment. The $<200 \mu \mathrm{m}$ treatment contained the natural assemblage of bacteria, algae, protozoa and other microzooplankton. The $<1.2 \mu \mathrm{m}$ treatment was the same, except that the water was gently filtered through a GF/C glass-fiber filter to remove algae, protozoa and other microzooplankton. Thus, the $<1.2 \mu \mathrm{m}$ treatment is a control for net changes in zoospores concentration caused by cell losses due to other factors than grazing and due to division.

$150 \mathrm{ml}$ of the $<200 \mu \mathrm{m}$-filtered or $100 \mathrm{ml}$ of the $<1.2$ $\mu \mathrm{m}$-filtered water was added to each $250 \mathrm{ml}$ polycarbonate bottle. At time $t=0$, an aliquot of the stained Pfiesteria piscicida culture grown at the appropriate salinity was added to each replicate to achieve a calculated density of 500 cells $\mathrm{ml}^{-1}$. The incubation bottles were gently mixed by inverting them several times and then samples were immediately withdrawn and fixed for determination of initial concentrations of stained P. piscicida. The bottles were then incubated in the dark at 22 to $24^{\circ} \mathrm{C}$ and sampled after $0.5,1,1.5,2,3,4$ and $5 \mathrm{~h}$.

Community growth or grazing coefficient for each replicate was calculated using data on free-stained Pfiesteria piscicida zoospore concentrations from all time points (example shown in Fig. 2) using the approach developed by Frost (1972) for measuring zooplankton grazing. For each replicate, the slope of a regression of the natural $\log (\mathrm{ln})$ of zoospores $\mathrm{ml}^{-1}$ versus time was calculated. The slope of the $<200 \mu \mathrm{m}$ treatment is an estimate of net growth rate, $K$, of zoospores in the presence of the natural microzooplankton assemblage. The slope for the $<1.2 \mu \mathrm{m}$ treatment is an estimate of the rate of increase or decrease, $\mu$, of zoospores in the absence of grazing. The estimate of ' $\mu$ ' is a minimum estimate since the $1.2 \mu \mathrm{m}$ filtration removed potential

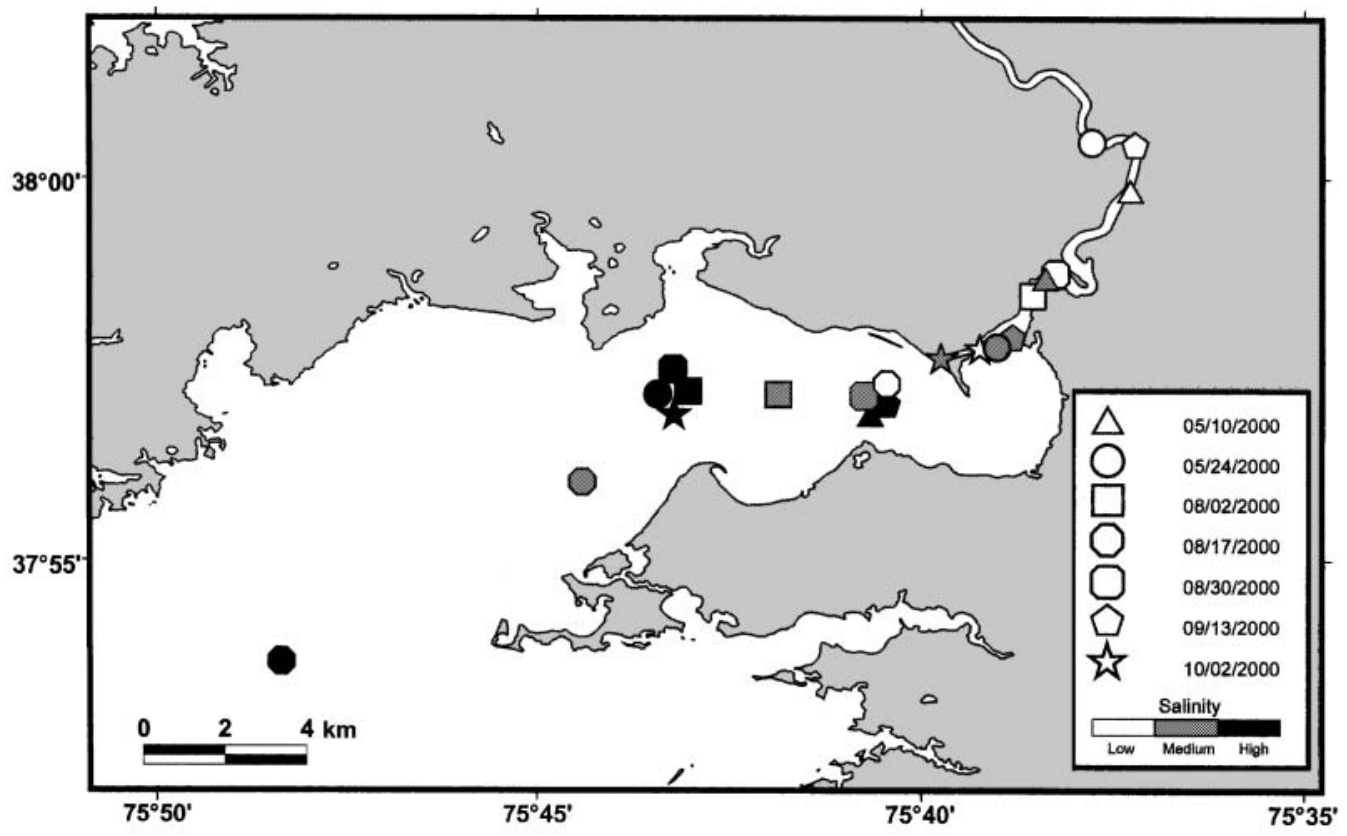

Fig. 1. Sampling stations on the Pocomoke River for collection of high (H), medium (M) and low (L) salinity surface water 


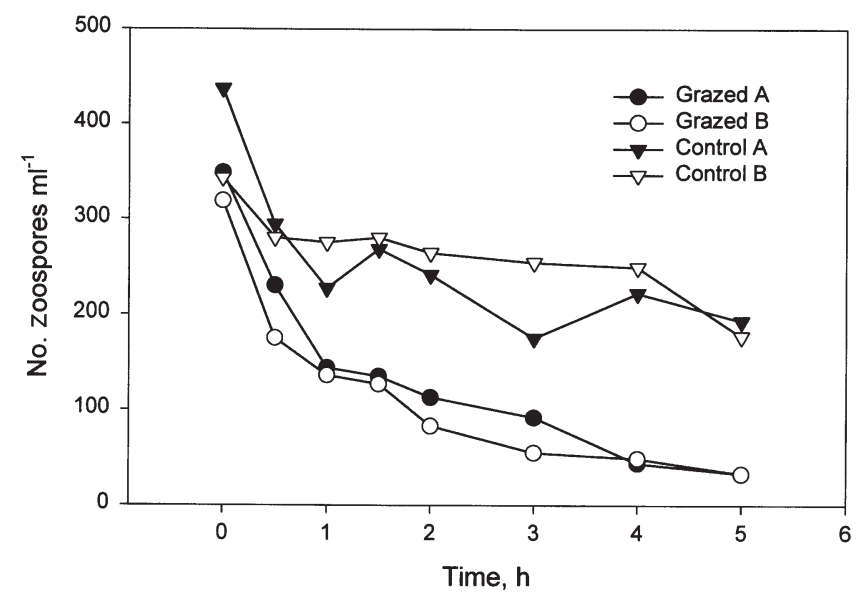

Fig. 2. Pfiesteria piscicida. Changes in concentration of added fluorescent-labeled zoospores during the grazing experiment conducted on 10 May 2000. Data are shown for incubations with surface water from the 'high' salinity station (see Table 1). In the duplicate grazed bottles, zoospores were added to surface water that had been screened through a $200 \mu \mathrm{m}$ mesh and thus contained microzooplankton but not mesozooplankton. In the duplicate control bottles, zoospores were added to surface water that had been filtered through a GF/C glass-fiber filter (mesozooplankton and microzooplankton removed)

prey for $P$. piscicida as well as its potential predators. A minimum estimate of the grazing coefficient, $g$, for each replicate of the $<200 \mu \mathrm{m}$ treatment was calculated as $\mu-K_{\text {; }}$ the average ' $\mu$ ' for the $<1.2 \mu \mathrm{m}$ treatment was used in the calculation.

Statistical analysis. All statistics were done using Jandel SigmaStat Version 2.0.

\section{RESULTS}

\section{Environmental conditions}

The positions in the Pocomoke sub-estuary, where it was possible to collect high (H)-, medium (M)- and low (L) salinity surface water varied with sampling date. On 17 August 2000, which was after a rainy period, stations were displaced seaward, with all stations displaced to Pocomoke Sound. In contrast, on 10 May and 9 September, the $\mathrm{L}$ and $\mathrm{M}$ stations were located in the river proper (Fig.1). Surface water matching the target salinity was not always obtained. The $\mathrm{H}$ stations varied between 11.4 and $15.6 \mathrm{psu}$, the $\mathrm{M}$ stations between 7.8 and $11.2 \mathrm{psu}$, and the $\mathrm{L}$ stations between 2.0 and 5.9 psu (Table 1).

Temperature varied among dates, with the lowest water temperatures (19 to $20^{\circ} \mathrm{C}$ ) on 24 May and 2 Octo- ber and the highest water temperatures $\left(26\right.$ to $\left.27^{\circ} \mathrm{C}\right)$ on 2 August. There was little difference in water temperature among $\mathrm{H}, \mathrm{M}$ and $\mathrm{L}$ stations on any 1 sampling date (Table 1).

The phytoplankton assemblages varied with date and station (Table 1). Centric diatoms were observed in all samples, and consistent patterns in their abundance were not observed. Cryptophytes were usually less abundant in the $\mathrm{H}$ sample than at in the $\mathrm{M}$ or $\mathrm{L}$ samples. Photosynthetic dinoflagellates were more abundant in the summer samples than in the spring or fall samples (Table 1), and common species were Karlodinium micrum (= Gyrodinium galatheanum) and Prorocentrum minimum.

Microzooplankton also varied with sampling date and salinity (Table 1). The photosynthetic ciliate Mesodinium rubrum (= Myrionecta rubra) occurred at densities $>100 \mathrm{ml}^{-1}$ in 3 of the samples with a salinity $<8 \mathrm{psu}$ (Table 1). Small $(\leq 20 \mu \mathrm{m})$ ciliates included choreotrichs, strombidiids, cf. Mesodinium pulex and the bacterivorous scuticociliates. Large ciliates $(>20$ $\mu \mathrm{m})$ included strombidiids and tintinnids. Both small and large ciliates tended to be low in abundance in samples with a salinity $<7$ psu (Table 1). Small ciliates declined in abundance between May and October (Table 1). Heterotrophic dinoflagellates were mostly small, non-thecate types and included Gyrodinium spp. and Oxyhrris sp. Except on 17 August, heterotrophic dinoflagellates were relatively low in abundance at the low-salinity station (Table 1). Pfiesteria-like cells were always low in abundance (Table 1). Metazoan microzooplankton, including rotifers, copepod nauplii and benthic invertebrate larvae occurred at densities of $<2 \mathrm{ml}^{-1}$ (data not shown).

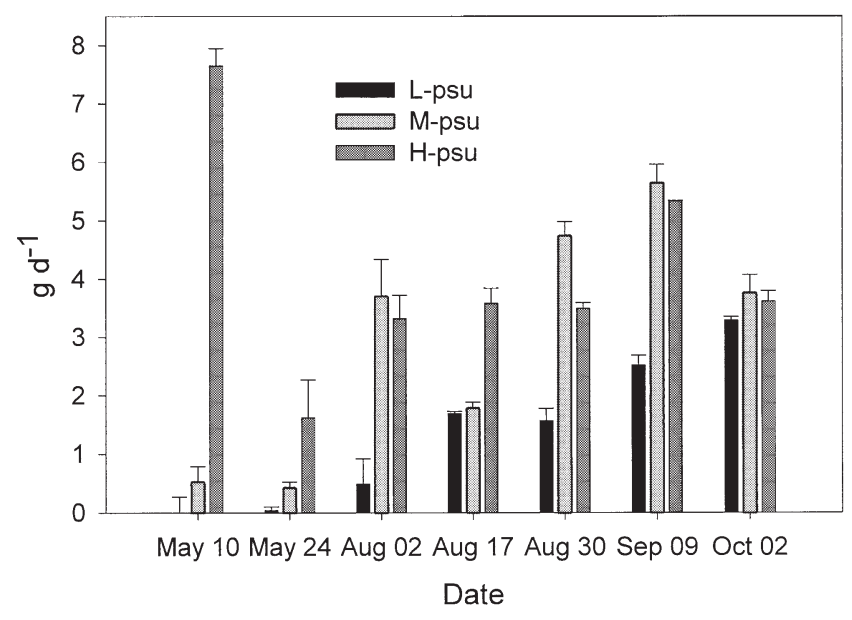

Fig. 3. Potential grazing coefficients of natural assemblages of microzooplankton on Pfiesteria piscicida zoospores in high-, medium- and low-salinity surface waters, Pocomoke River and Sound, 2000. Means \pm SD 
Table 1. Salinity, in situ water temperature, and composition of microplankton assemblages (cells ml ${ }^{-1}$ ) at high $(\mathrm{H})$, medium (M) and low-salinity stations, Pocomoke River, 2000. Ciliates $\leq 20$ and $>20 \mu \mathrm{m}$ choreotrichs and strombidiids and Mesodinium rubrum $(\mathrm{Meso})_{;}$Het: heterotrophic dinoflagellates; Photo: autotrophic and mixotrophic dinoflagellates; Cryp: cryptophytes; Diat: centric diatoms; P-like: Pfiesteria-like dinoflagellates (also included in heterotrophic dinoflagellates); ns: no sample

\begin{tabular}{|c|c|c|c|c|c|c|c|c|c|c|}
\hline $\begin{array}{l}\text { Date } \\
\text { Site }\end{array}$ & $\begin{array}{l}\text { Salinity } \\
\text { (psu) }\end{array}$ & $\begin{array}{c}\text { Temp. } \\
\left({ }^{\circ} \mathrm{C}\right)\end{array}$ & $\leq 20 \mu \mathrm{m}$ & $\begin{array}{l}\text { Ciliates } \\
>20 \mu \mathrm{m}\end{array}$ & Meso & \multicolumn{2}{|c|}{ Dinoflagellates } & Cryp & $\begin{array}{c}\text { Other } \\
\text { Diat }\end{array}$ & $P$-like \\
\hline \multicolumn{11}{|c|}{10 May } \\
\hline $\mathrm{H}$ & 11.4 & 23.3 & 199 & 9 & 16 & 50 & 6 & 12 & 47 & 3 \\
\hline $\mathrm{M}$ & 7.8 & 23.4 & 50 & 17 & 360 & 12 & 6 & 48 & 17 & 1 \\
\hline $\mathrm{L}$ & 4.9 & 23.6 & 0 & 0 & 765 & 6 & 0 & 96 & 17 & 4 \\
\hline \multicolumn{11}{|c|}{24 May } \\
\hline $\mathrm{H}$ & 15.3 & 19.6 & 63 & 6 & 6 & 82 & 6 & 6 & 22 & 9 \\
\hline $\mathrm{M}$ & 10.7 & 19.8 & 23 & 23 & 13 & 13 & 6 & 13 & 17 & 8 \\
\hline $\mathrm{L}$ & 5.0 & 20.6 & 16 & 6 & 31 & 16 & 0 & 26 & 25 & $\leq 2$ \\
\hline \multicolumn{11}{|c|}{02 Aug } \\
\hline $\mathrm{H}$ & 12.7 & 26.8 & 53 & 31 & 9 & 100 & 6 & 9 & 97 & 6 \\
\hline $\mathrm{M}$ & 9.2 & 26.9 & 37 & 37 & 7 & 107 & 43 & 7 & 197 & 3 \\
\hline $\mathrm{L}$ & 2.0 & 26.7 & 13 & 0 & 0 & 9 & 47 & 9 & 63 & 3 \\
\hline \multicolumn{11}{|c|}{17 Aug } \\
\hline $\mathrm{H}$ & 15.6 & 24.6 & 16 & 19 & 0 & 41 & 53 & 12 & 110 & 2 \\
\hline $\mathrm{M}$ & 10.6 & 24.4 & 23 & 10 & 10 & 67 & 53 & 24 & 73 & 3 \\
\hline $\mathrm{L}$ & 3.8 & 25.1 & 22 & 0 & 6 & 44 & 12 & 12 & 50 & $\leq 2$ \\
\hline \multicolumn{11}{|c|}{30 Aug } \\
\hline $\mathrm{H}$ & 14.6 & 25.4 & 13 & 6 & 0 & 104 & 16 & 6 & 138 & 8 \\
\hline $\mathrm{M}$ & 11.2 & 25.5 & 13 & 13 & 0 & 137 & 80 & 13 & 110 & 19 \\
\hline $\mathrm{L}$ & 5.9 & 25.5 & 0 & 9 & 6 & 13 & 135 & 6 & 41 & 2 \\
\hline \multicolumn{11}{|c|}{$13 \mathrm{Sep}$} \\
\hline $\mathrm{H}$ & 14.4 & 25.2 & 6 & 9 & 6 & 163 & 56 & 6 & 72 & ns \\
\hline $\mathrm{M}$ & 10.0 & 25.4 & 0 & 7 & 0 & 33 & 814 & 12 & 0 & ns \\
\hline $\mathrm{L}$ & 4.3 & 25.9 & 0 & 0 & 491 & 9 & 205 & 48 & 16 & ns \\
\hline \multicolumn{11}{|l|}{02 Oct } \\
\hline $\mathrm{H}$ & 15.3 & 18.7 & 2 & 16 & 0 & 110 & 9 & 6 & 69 & $\leq 2$ \\
\hline $\mathrm{M}$ & 10.0 & 19.9 & 7 & 33 & 10 & 14 & 43 & 13 & 30 & $\leq 2$ \\
\hline $\mathrm{L}$ & 5.9 & 19.3 & 0 & 9 & 25 & 0 & 31 & 12 & 25 & $\leq 2$ \\
\hline
\end{tabular}

\section{Potential grazing by microzooplankton on Pfiesteria piscicida}

Potential grazing on non-toxic zoospores of Pfiesteria piscicida was high, with an average grazing coefficient, $g$, of $2.8 \mathrm{~d}^{-1}$ (Fig. 3). Variation among dates was significant, with the lowest average $g$ for the $H, M$ and L salinity samples $\left(0.6 \mathrm{~d}^{-1}\right)$ occurring on 24 May (Fig. 3, Table 2). Grazing on zoospores was always lowest in the L sample (Fig. 3), with salinity range having a significant effect on the grazing coefficient (Table 3). Salinity accounted for about $26 \%$ of the variability in the grazing coefficient (Fig. 4). The potential grazing coefficient could also be predicted from the species composition of the microplankton assemblage, with a combination of cryptophyte abundance, photosynthetic dinoflagellate abundance and small ciliate abundance accounting for about $67 \%$ of the variability in $g$ (Table 4). Inclusion of the abundance of Mesodinium rubrum, $>20 \mu \mathrm{m}$ ciliates, and diatoms and salinity did not significantly improve the fit of the regression model (Table 4). Grazing was positively associated with dinoflagellate and ciliate abundance but negatively with cryptophyte abundance.

Table 2. Comparison among dates of potential microzooplankton grazing $\left(\mathrm{g} \mathrm{d}^{-1}\right)$ on NON-IND Pfiesteria piscicida zoospores, Pocomoke River, 2000

\begin{tabular}{|c|c|c|c|c|}
\hline Date & \multicolumn{2}{|c|}{ Mean } & \multicolumn{2}{|c|}{$\mathrm{SE}$} \\
\hline 10 May & \multicolumn{2}{|c|}{2.95} & \multicolumn{2}{|c|}{1.498} \\
\hline 24 May & \multicolumn{2}{|c|}{0.64} & \multicolumn{2}{|c|}{0.338} \\
\hline 02 Aug & \multicolumn{2}{|c|}{2.52} & \multicolumn{2}{|c|}{0.689} \\
\hline 17 Aug & \multicolumn{2}{|c|}{2.36} & \multicolumn{2}{|c|}{0.399} \\
\hline $30 \mathrm{Aug}$ & \multicolumn{2}{|c|}{3.26} & \multicolumn{2}{|c|}{0.588} \\
\hline 13 Sep & \multicolumn{2}{|c|}{4.49} & \multicolumn{2}{|c|}{0.636} \\
\hline 02 Oct & \multicolumn{2}{|c|}{3.53} & \multicolumn{2}{|c|}{0.128} \\
\hline \multicolumn{5}{|c|}{ One-way ANOVA } \\
\hline Source of variation & $\mathrm{df}$ & MS & $F$ & $\mathrm{p}$ \\
\hline Among dates & 6 & 0.0149 & 2.663 & 0.03 \\
\hline Residual & 35 & 0.0056 & & \\
\hline Total & 41 & & & \\
\hline
\end{tabular}


Table 3. Comparison among high-, medium- and low-salinity stations of potential microzooplankton grazing $\left(\mathrm{g} \mathrm{d}^{-1}\right)$ on NON-IND Pfiesteria piscicida zoospores, Pocomoke River, 2000. ns: not significant

\begin{tabular}{|c|c|c|c|c|}
\hline Station & & Mean & & SE \\
\hline High & & 4.08 & & 0.502 \\
\hline Medium & & 2.93 & & 0.540 \\
\hline Low & & 1.46 & & 0.305 \\
\hline \multicolumn{5}{|c|}{ One-way ANOVA } \\
\hline Source of variation & df & MS & $F$ & $\mathrm{p}$ \\
\hline Among stations & 2 & 0.0421 & 8.172 & 0.001 \\
\hline Residual & 39 & 0.0052 & & \\
\hline Total & 41 & & & \\
\hline \multicolumn{5}{|c|}{ Pairwise multiple comparison (Tukey test) } \\
\hline \multicolumn{3}{|c|}{ Comparison } & \multicolumn{2}{|c|}{$\mathrm{p}$} \\
\hline \multirow{3}{*}{\multicolumn{2}{|c|}{$\begin{array}{l}\text { High vs Low } \\
\text { High vs Medium } \\
\text { Medium vs Low }\end{array}$}} & \multicolumn{3}{|c|}{$<0.05$} \\
\hline & & \multicolumn{3}{|c|}{ ns } \\
\hline & & \multicolumn{3}{|c|}{ ns } \\
\hline
\end{tabular}

\section{DISCUSSION}

During 2000, the average potential microzooplankton grazing coefficient in the Pocomoke River and Sound on non-toxic zoospores of Pfiesteria piscicida was $>2 \mathrm{~d}^{-1}$ at stations with a surface salinity $\geq 6$ psu (Tables $1 \& 3$, Fig. 3). Since the maximum specific growth rate, $\mu$, of non-toxic zoospores is 1 to $2 \mathrm{~d}^{-1}$ (Glasgow et al. 1998, Stoecker et al. 2000, Burkholder et al. 2001), it should not have been possible for zoospore populations to increase in the more saline waters. An exception was in May, when low grazing coefficients were observed at salinities $>6$ psu (Fig. 3). At the low-salinity stations (2 to $6 \mathrm{psu}$ ) the average potential grazing was $1.46 \mathrm{~d}^{-1}$,

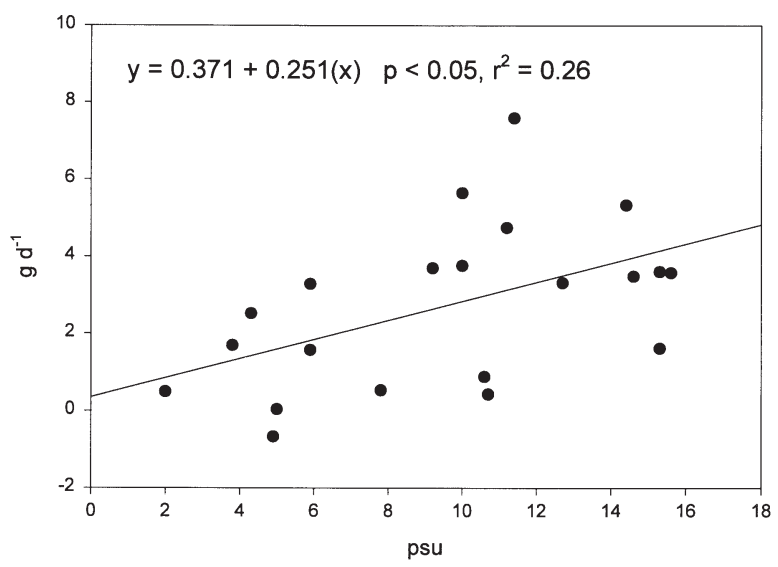

Fig. 4. Potential microzooplankton grazing on Pfiesteria piscicida zoospores as a function of salinity with coefficients of $<1 \mathrm{~d}^{-1}$ occurring in May and in early August. Thus, windows with low grazing pressure occurred in which net growth of non-toxic zoospores might have been possible. These windows were most common in low-salinity water in late spring. In contrast, in 12 to 16 psu surface waters of the Chicamacomico River in 1999, mean grazing coefficients were also usually high, but windows of low grazing were observed sporadically during mid summer. In both cases Pfiesteria-like dinoflagellates were not abundant and toxic outbreaks did not occur.

In laboratory experiments, grazing by microzooplankton on TOX-A is lower than on TOX-B and NONIND zoospores (Stoecker et al. 2001). Grazing control of zoospores may be low during toxic events when TOX-A zoospores are dominant.

In the study conducted in the Chicamacomico River in 1999, the most commonly observed micrograzers with ingested zoospores were tintinnid ciliates and Strombidium spp. (Stoecker et al. 2000). In the experiments with Pocomoke River samples, we commonly observed small non-thecate heterotrophic dinoflagellates (Oxyhrris spp. and Gyrodinium spp.) with ingested labelled zoospores. Some mixotrophic dinoflagellates can also consume Pfiesteria piscicida non-toxic zoospores (Stoecker et al. 2000). Potential microzooplankton grazing on $P$. piscicida was positively associated with densities of small ciliates and dinoflagellates (Table 4). It is interesting that grazing was negatively associated with cryptophyte abundance. Cryptophytes are a particularly good food for growth of zoospores, and are sources of kleptochloroplasts (stolen chloroplasts) that can provide photosynthate to P. piscicida (Burkholder \& Glasgow 1995, Glasgow et al. 1998, Lewitus et al. 1999). Estuarine waters rich in cryptophytes should be favorable to net growth of $P$. piscicida populations because of relatively high growth rates coupled to low grazing mortality.

Mesozooplankton, including copepods and rotifers, also graze on Pfiesteria piscicida zoospores (Burk-

Table 4. ANOVA of prediction of microzooplankton grazing coefficient $\left(\mathrm{g} \mathrm{d}^{-1}\right)$ on NON-IND Pfiesteria piscicida zoospores from protist abundance (Table 1). Variables chosen with a 'best subsets regression' with adjusted $\mathrm{R}^{2}$ as best criterion. $\mathrm{g} \mathrm{d}^{-1}=1.187-(0.0215 \times$ cryp $)+(0.00556 \times$ pdin $)+(0.0182 \times$ hdin $)+(0.0217 \times \leq 20$ cil $) ; N=21 ; R^{2}=0.667$; adjusted $R^{2}=$ 0.584 ; $\mathrm{SE}$ of estimate $=1.343$, where cryp $=$ cryptophytes $\mathrm{ml}^{-1}$; pdin $=$ autotrophic or mixotrophic dinoflagellates $\mathrm{ml}^{-1}$; hdin $=$ heterotrophic dinoflagellates $\mathrm{ml}^{-1}$

\begin{tabular}{|lcccc|}
\hline Source of variation & df & MS & $F$ & $p$ \\
\hline Regression & 4 & 14.463 & 8.017 & $<0.001$ \\
Residual & 16 & 1.804 & & \\
Total & 20 & 4.336 & & \\
\hline
\end{tabular}


holder \& Glasgow 1995, Mallin et al. 1995). However, grazing by microzooplankton is probably a more important mortality factor for zoospores than grazing by mesozooplankton. During the late spring and summer, the dominant copepod in mesohaline waters of Chesapeake Bay is Acartia tonsa. Mean adult and copepodite densities are about 6 adults and 8 copepodites $l^{-1}$ (Chesapeake Bay Program, Stn ET5.2, May to Oct 1997 to 1999: www.chesapeakebay.net). In mesohaline waters of Chesapeake Bay, mean clearance rates of $A$. tonsa adults and copepodites is about 7 and $3 \mathrm{ml}$ ind. ${ }^{-1} \mathrm{~d}^{-1}$, respectively (White \& Roman 1992). Assuming that similar values apply to the Pocomoke and Chicamacomico Rivers, this would result in average grazing coefficients of copepods on the order of $0.1 \mathrm{~d}^{-1}$, which is much lower than the measured grazing coefficients of microzooplankton assemblages (Stoecker et al. 2000 and data presented herein). Copepod grazing may indirectly have a negative effect on the total grazing pressure on zoospores because copepods have higher clearance rates for ciliates than they do for small flagellates such as $P$. piscicida zoospores (Stoecker \& Sanders 1985, Gifford \& Dagg 1988, Hansen et al. 1994). Microzooplankton populations, particularly planktonic ciliates, respond quickly to changes in mesozooplankton abundance, and, in turn, microzooplankton strongly control $<15 \mu \mathrm{m}$ flagellates (Miller et al. 1995, Adrian et al. 2001).

Differences in community structure and productivity along salinity gradients (Marshall \& Nesius 1993, Sin et al. 2000) may influence the net growth of non-toxic zoospores both by controlling availability of prey for zoospores and by affecting grazing pressure. Cryptophytes are ubiquitous in oligohaline and mesohaline regions of tidal estuaries in the lower Chesapeake Bay (Marshall \& Nesius 1993). This should favor net growth of Pfiesteria piscicida zoospores. Dinoflagellates, which are associated with high grazing coefficients on zoospores, are less abundant in the upper, oligohaline sections of tidal rivers than in the middle and lower, more saline, sections (Marshall \& Nesius 1993). Higher nutrient levels in the upper, less saline, sections of tidal rivers, such as the Pocomoke (Maryland Department of Natural Resources 1998), may be associated with reduced grazing pressure. Eutrophication of tidal rivers is correlated with a decrease in total micro- and mesozooplankton biomass and specifically with a decrease in tintinnid biomass at mesohaline stations (Park \& Marshall 2000). Presumably, eutrophication would result in decreased grazing pressure on small dinoflagellates such as $P$. piscicida. Freshets that reduce salinity as well as increase nutrient loading in estuaries may provide windows of opportunity for net growth of zoospore populations due to increased avail- ability of prey (Glibert et al. 2001) and reduction in grazing mortality. The relationships among these factors and their relative importance as antecedent conditions for toxic $P$. outbreaks remain to be investigated.

Acknowledgements. We thank Dr K. A. Steidinger for kindly providing us with a strain of Pfiesteria piscicida. We thank other members of the ECOHAB project at Horn Point Laboratory for their input and support, especially Drs M. Roman and P. M. Glibert, Ms Erin Haramoto, Mark Trice and Jeff Alexander. Mark Trice provided Fig. 1. Supported by NOAA grant NA86OP0493 (EcoHab contribution number 35). Contribution number 3506 from UMCES.

\section{LITERATURE CITED}

Adrian R, Wickham SA, Butler NM (2001) Trophic interactions between zooplankton and the microbial community in contrasting food webs: the epilimnion and deep chlorophyll maximum of a mesotrophic lake. Aquat Microb Ecol 24:83-97

Burkholder JM, Glasgow HB Jr (1995) Interactions of a toxic estuarine dinoflagellate with microbial predators and prey. Arch Protistenkd 145:177-188

Burkholder JM, Glasgow HB Jr (1997a) Pfiesteria piscicida and other Pfiesteria-like dinoflagellates: behavior, impacts, and environmental controls. Limnol Oceanogr 42: 1052-1075

Burkholder JM, Glasgow HB Jr (1997b) Trophic controls on stage transformations of a toxic ambush-predator dinoflagellate. J Eukaryot Microbiol 44:200-205

Burkholder JM, Noga EJ, Hobbs CH, Glasgow HB Jr (1992) New 'phantom' dinoflagellate is the causative agent of major estuarine fish kills. Nature 348:407-410

Burkholder JM, Glasgow HB Jr, Hobbs CW (1995) Fish kills linked to a toxic ambush-predator dinoflagellate: distribution and environmental conditions. Mar Ecol Prog Ser 124: $43-61$

Burkholder JM, Glasgow HB Jr, Deamer-Melia NJ (2001) Overview and present status of the toxic Pfiesteria complex. Phycologia 40:186-214

Frost BW (1972) Effects of size and concentration of food particles on the feeding behavior of the marine planktonic copepod Calanus pacificus. Limnol Oceanogr 17:805-815

Gifford DJ, Dagg MJ (1988) Feeding of the estuarine copepod Acartia tonsa Dana: carnivory vs. herbivory in natural microplankton assemblages. Bull Mar Sci 43:458-468

Glibert PM, Magnien R, Lomas MW, Alexander J, Fan C, Haramoto E, Trice M, Kana TM (2001) Harmful algal blooms in the Chesapeake and Coastal Bays of Maryland, USA: comparison of 1997, 1998, and 1999 Events. Estuaries 24:875-883

Glasgow HB Jr, Lewitus AJ, Burkholder JM (1998) Feeding behavior of the ichthyotoxic estuarine dinoflagellate, Pfiesteria piscicida, on amino acids, algal prey, and fish vs. mammalian erythrocytes. In: Reguera B, Blanco J, Fernández ML, Wyatt T (eds) Harmful algae. Xunta de Galicia and Intergovernmental Oceanographic Commission of UNESCO, Paris, p 394-397

Hallegraeff GM (1993) A review of harmful algal blooms and their apparent global increase. Phycologia 32:79-99

Hansen B, Bjørnsen PK, Hansen PJ (1994) The size ratio between planktonic predators and their prey. Limnol Oceanogr 39:395-403

Kamiyama T (2000) Application of a vital staining method to 
measure feeding rates of field ciliate assemblages on a harmful alga. Mar Ecol Prog Ser 197:299-303

Lewitus AJ, Glasgow HB Jr, Burkholder JM (1999) Kleptoplastidy in the toxic dinoflagellate Pfiesteria piscicida (Dinophyceae). J Phycol 35:303-312

Li A, Stoecker DK, Coats DW, Adam EJ (1996) Ingestion of fluorescently labeled and phycoerythrin-containing prey by mixotrophic dinoflagellates. Aquat Microb Ecol 10:139-147

Mallin MA, Burkholder JM, Larsen LM, Glasgow HB Jr (1995) Response of two zooplankton grazers to an ichthyotoxic estuarine dinoflagellate. J Plankton Res 17:351-363

Marshall HG, Nesius KK (1993) Seasonal relationships between phytoplankton composition, abundance and promary productivity in three tidal rivers of the lower Chesapeake Bay. J Elisha Mitchell Sci Soc 109:141-151

Marshall HG, Gordon AS, Seaborn DW, Dyer B, Dunstan WM, Seaborn AM (2000) Comparative culture and toxicity studies between the toxic dinoflagellate Pfiesteria piscicida and a morphologically similar cryptoperidiniopsoid dinoflagellate. J Exp Mar Biol Ecol 255:51-74

Maryland Department of Natural Resources (1998) Water quality, habitat and biological conditions of river systems affected by Pfiesteria or Pfiesteria-like organisms on the lower Eastern shore of Maryland: 1997 summary. Document \#DNR\RAS\TEA-1998-1. Maryland Department of Natural Resources, Annapolis

Miller CA, Penry DL, Glibert PM (1995) The impact of trophic interactions on rates of nitrogen regeneration and grazing in Chesapeake Bay. Limnol Oceanogr 40:1005-1011

Editorial responsibility: Otto Kinne (Editor), Oldendorf/Luhe, Germany
Park GS, Marshall HG (2000) Estuarine relationships between zooplankton community structure and trophic gradients. J Plankton Res 22:121-135

Sieracki ME, Verity PG, Stoecker DK (1993) Plankton community response to sequential silicate and nitrate depletion during the 1989 North Atlantic spring bloom. DeepSea Res Part II 40:213-225

Sin Y, Wetzel RL, Anderson IC (2000) Seasonal variations of size-fractionated phytoplankton along the salinity gradient in the York River estuary, Virginia (USA). J Plankton Res 22:1945-1960

Steidinger KA, Burkholder JM, Glasgow HB Jr, Hobbs CW, Garrett JK, Truby EW, Noga EJ, Smith SA (1996) Pfiesteria piscicida gen. et sp. nov. (Pfiesteriaceae fam. nov.), a new toxic dinoflagellate with a complex life cycle and behavior. J Phycol 32:157-164

Stoecker DK, Sanders NK (1985) Differential grazing by Acartia tonsa on a dinoflagellate and a tintinnid. J Plankton Res 7:85-100

Stoecker DK, Stevens K, Gustafson DE Jr (2000) Grazing on Pfiesteria piscicida by microzooplankton. Aquat Microb Ecol 22:261-270

Stoecker DK, Parrow MW, Burkholder JM, Glasgow HB Jr (2002) Grazing by microzooplankton on Pfiesteria piscicida cultures with different histories of toxicity. Aquat Microb Ecol 28(1):79-85

White JR, Roman MR (1992) seasonal study of grazing by metazoan zooplankton in the mesohaline Chesapeake Bay. Mar Ecol Prog Ser 86:251-261

Submitted: June 25, 2001; Accepted: November 13, 2001 Proofs received from author(s): April 17, 2002 